\title{
ECOLOGY AND BEHAVIOR OF ASSAMESE MONKEYS IN SHIVAPURI NAGARJUN NATIONAL PARK, NEPAL
}

\author{
M.K. Chalise ${ }^{1}$, G.P. Bhattarai ${ }^{2}$ and B. Pandey ${ }^{2}$
}

\section{ABSTRACT}

The population distribution and diurnal behavior of Assamese monkey Macaca assamensis were studied in Shivapuri Nagarjun National Park, Nepal and data collected during Dec. 2011 to March 12 by scan sampling methods along with application of ArcGIS software. Seven bisexual troops were observed in subtropical/lower temperate forest of Shivapuri Nagarjun National Park and its marginal areas near to human settlement. The observed smallest troop was with 12 individuals while the largest troop had 35 individuals of different age. The average troop size is 23.71 with standard deviation 9.22 . Out of three broad age groups adults were $40.27 \%$, immature $42.95 \%$ and infants were $14.09 \%$. The sex ratio between male and female was 1:1.03.

A troop was selected as focal troop for behavioral study after habituation. Foraging/eating covered $46 \%$ of total observed time while resting $19 \%$, locomotion $16 \%$, sleeping $12 \%$, grooming $6 \%$, and playing $1 \%$. Some other behavior noticed such as aggression, copulation, stone licking, coughing and sniffing for short duration. Young and tender leaves as well as burgeoning twigs were primary sources of food $(38.24 \%)$ for winter followed by seeds $(35.29 \%$, moss and epiphytes $(14.71 \%)$, insects $(5.88 \%)$ and others $5.88 \%$. while water drinking was never observed. All troops in Shivapuri forest were found residing on the steep cliffs along with river bank while Nagarjun forest troops used cliff as well as tall trees.

Key words: Macaca assamensis, troops, population, behavioral pattern, Nepal

\section{INTRODUCTION}

The legally protected animal Assamese monkey (Macaca assamensis) was first recorded in 1985 in Shivapuri Nagarjun National Park and thereafter remained unknown in the area for a long time. However, the present study revealed that there are a considerable number of troops (Seven troops) with the size of 23.71 in average with the standard deviation of 9.92. Nepal has three species of the monkeys such as Rhesus monkey Macaca mulata, Zimmermann 1780, Assamese monkey, Macaca assamensis, McClelland 1840 (2 subspecies ?), and Hanuman langur, Semnopithecus entellus, Dufrense 1797 (3 subspecies) (Menon 2003, Chalise et al. 2005, Chalise 2012, 2012a). Assamese monkey is locally known as Pahare Bandar and commonly as Assami Bandar in Nepal which closely resembles with the Rhesus monkeys.

Assamese monkey resembles the Rhesus Monkey having a brownish-grey to yellowish-grey coat, which is uniform in pelage, lacks a pinkish face and absence of red loins/buttock. It has darker fur in exposed area while whitish-blonde haired to ashy-white in abdominal and inner parts. Male has dark purple (egg-plant color) snout particularly around the nose while 
female has crimsoned red to pinkish red around the eyes and cheeks. Local saying appropriately reflects the fur color variation within a group as this species is called 'Missal'- means mixed color. The palm, sole and nails are dirty brown/black in color. The ischial callosities in male are conspicuous from a distance and distinct in darker individuals. In higher elevation, the animals are with darker fur on back and whitish in abdominal parts resembling Tibetan monkey. However, a distinct difference in color was also found in higher elevation and lower elevation of the country, as it is recorded from $380 \mathrm{~m}$ asl to $2350 \mathrm{~m}$ asl in Nepal (Chalise 2003, 2008, 2008a, Chalise 2011). The macaque male has a dark beard on the cheeks which are found directed backwards to the ears while the hair on the crown is divided from the middle. It is a thickest Macaque in the wild, which travels along the ground laying its tail parallel to the ground (Menon 2003)

The Assamese monkey is a large sized monkey weighing from 5-10 kilograms with a range of $51-73.5 \mathrm{~cm}$ with $15-30 \mathrm{~cm}$ long tail. It is a diurnal animal feeds on vegetables, cereals, twigs, and invertebrates with arboreal habit (Chalise 2000, 2003, Menon 2003). The Assamese monkeys (Macaca assamensis) of Nepal are considered 'Nepal Population' by CAMP workshop 2002 (Conservation Assessment and Management Plan) due to taxonomic confusion (Chalise 2010, Sanjaya et al. 2003). This population is different from Assamese monkeys described so far from this region with respect to the head-body length, tail length, T/HB ratio, body weight and fur coloration and its distribution in Nepal. It might be endemic to Nepal (Chalise 2008, 2011). Therefore, socio-ecology and general behavior of this monkey species of Nepal could be of great importance for the purpose of species conservation and management (Chalise 2000, 2003, 2005). In Nepal, it is reported to cover wider geographical ranges, rather fragmented population, distributed along rivers in the tropical and subtropical areas. The reported areas start from Kankai valley of Ilam, Sabhaya Valley and its range further extended west to Makalu Barun National Park (MBNP), Melamchi, Langtang National Park, Nagarjun Area of Shivapuri Nagarjun National Park (SNNP), Makwanpur Dhading, Myagdi, Ramdi Palpa and Achham district (Chalise 2003, 2008, Wada 2005) to Chamelia river basin (N 2948'34.6" E $080^{\circ} 51^{\prime} 02.8$ ", $1607 \mathrm{~m}$ ) of Api Nampa Conservation Area (Chalise pers.obs. 2013). Besides Nepal, this species has been reported from India (Medhi et al. 2007), Bhutan (Kawamoto, et al. 2006) Myanmar, Bangladesh (Menon 2003, Chalise 2011) Thailand, and southernmost China and Laos (Zhou et al. 2011, Timmins and Duckworth 2013).

The Assamese monkey is a legally protected animal by the National Parks and Wildlife Conservation Act, 1973, Nepal. This animal has a strict protection mechanism in its range countries and has listed as a schedule-I animal whose poaching is fully restricted. Similarly, the International Union for Conservation of Wild Flora and Fauna (IUCN) has listed this animal under Near Threatened (NT) animal (IUCN 2011) while its trade in international market has been regulated by the Convention on International Trade of Endangered Species of Wild Flora and Fauna (CITES) grouping under Schedule II animal (Chapagain and Dhakal 2002, Boonratana et al. 2008, CITES 2012). 
tion with the park authorities was made for this purpose along with security personnel and local forest users. The areas with steep cliff and deep gorges were the preferred habitat for these Macaques (Chalise 2003). Such areas are considered as focal areas (Chalise 2010) to find the species. The vicinities human settlements of such areas were selected for informal interviews.

\section{GIS mapping}

The location of each troop was recorded using GPS (Garmin etrex $\mathrm{H}$ personal navigator). The Mahabhir troop and Alchhe khola troop was monitored to understand the home range during this study. Distribution map and seasonal range maps were prepared using ArcGIS 9.3 software.

\section{Observation}

The study areas were surveyed walking along the forest trail taken it as the transect line. After several visits to different spots, areas with high primate availability were selected as "focal areas". Such focal areas were frequently visited on foot and the selected group, "focal group", was studied. The focal group members were classified according to age and sex (Chalise 1997). The duration of any behavior and activities were recorded on the protocol papers with the help of binocular and watch. The individual counting and identification of groups were repeated several times in one observation session. The data obtained from this procedure gave insight for the determination of average group size, composition and social structure of species. For the behavioral observations, continuous recording (or all occurrences recording) technique was used (Martin and Bateson 1993).

\section{Scan Sampling}

Behaviors were recorded using the scan sampling method (Altmann 1974) in every 15 minutes and as practiced in previous researches, a continuous average group scanning was carried out whenever monkeys are observed (Chalise 2003, 2010). Among the observed troop the area based "Alchhe/Sikre Khola" troop was selected as focal troop for behavioral studies. This troop was selected for this study which is less disturbed by anthropogenic activities. Habituation period lasted a month and half for this study. Diurnal activities were recorded from 7:00 AM to 6:00 PM covering 78.25 hours in the data collection.

\section{RESULTS AND DISCUSSION}

\section{Distribution}

Seven troops of different population sizes were observed in six potential sites were identified where likelihood of finding Assamese monkey is higher. The Assamese monkey in SNNP has found from Rholche/Cha-Gaun in East (0637835, 3079670) to Sanagaun (624630, 3071927) in West. Most of the troops were found inhabiting around higher cliffs (except Raniban and Sanagaun-Mudkhu troop whose residing area was not found). Small cascades accompany all the sites in Shivapuri. Altitudinal distribution covers from 1440 meters in Nagarjun Fulbari gate to Rholche/Cha-Gaun troop at an elevation of $1949 \mathrm{~m}$ (map 1).

During this study, all of the seven identified troops were observed in Schima-Castanopsis forest but some population of Assamese monkeys were expected in Oak forests around Chhap Bhanjyang and Aindada-Jamacho Gompa area. The troops from Shivapuri forest were 
observed on northern slope of mountain range while Sanagaun-Mudkhu troop was found on north-western slopes. In Nagarjun area Fulbari gate troop was found eastern slope and the Raniban troop was found on southern slopes (table 1). All the troops found confined around the park boundary frequently interacting with crop-field of nearby villages. In Nagarjun forest area habitat sharing with Rhesus was common and frequent conflict was observed. Interview with local people, forest goers, shopkeepers, and security personnel revealed the possibilities of Assamese monkeys in the forests of Chhap bhanjyang, Shivapuri peak, Nayagaun, Jitpurphedi in Shivapuri forest as well as in Jamacho Gompa-Aindanda area of Nagarjun forest (table 2).

Table 1. Location of Assamese monkey troops observed in SNNP.

\begin{tabular}{|l|l|l|l|l|l|}
\hline \multirow{2}{*}{ SN } & \multirow{2}{*}{ Troop name } & \multicolumn{2}{|c|}{ GPS (UTM) } & $\begin{array}{l}\text { Elevation } \\
\text { (Meters) }\end{array}$ & $\begin{array}{l}\text { Remarks I } \\
\text { Forest Area }\end{array}$ \\
\cline { 3 - 6 } & Latitude & Longitude & & Shivapuri Forest \\
\hline 1. & Rholche/Cha-Gaun & 0637835 & 3079670 & 1949 & Shivapuri Forest \\
\hline 2. & Mahabhir (Alchhe) & 0636521 & 3079190 & 1837 & Shivapuri Forest \\
\hline 3. & Alchhe/Sikre khola & 0635465 & 3079208 & 1785 & Shivapuri Forest \\
\hline 4. & Sinche & 0633127 & 3079680 & 1458 & Nagarjun Forest \\
\hline 5. & Fulbari Gate & 0627875 & 3070177 & 1355 & Nagarjun Forest \\
\hline 6. & Raniban troop & 0636412 & 3077410 & 1440 & Nagarjun Forest \\
\hline 7. & Sanagaun-Mudkhu & 0624630 & 3071927 & 1543 & \\
\hline
\end{tabular}

Table 2. Potential sites of Assamese monkey according to interview.

\begin{tabular}{|l|l|l|l|l|}
\hline \multirow{2}{*}{ SN } & \multirow{2}{*}{ Site } & \multicolumn{2}{|c|}{ Location } & \multirow{2}{*}{ Remarks/ Area } \\
\cline { 3 - 4 } & & \multicolumn{1}{|c|}{ Latitude } & \multicolumn{1}{c|}{ Longitude } & \\
\hline 1. & Jitpurphedi & 627321 & 3076897 & Shivapuri Forest \\
\hline 2. & Nayagaun & 627473 & 3078484 & Shivapuri Forest \\
\hline 3. & Chhap Bhanjyang & 636412 & 3077410 & Nagarjun Forest \\
\hline 4. & Aindada-Jamacho & 624602 & 3070735 & Nagarjun Forest \\
\hline 5. & Sanagaun-Aindada & 623599 & 3072322 & Nagarjun Forest \\
\hline 6. & Aindada & 622374 & 3071097 & Nagarjun Forest \\
\hline
\end{tabular}




\section{Population}

Individual head count was used for population census. Seven troops were identified in SNNP. The smallest one was Mahabhir/Alchhe troop in Alchhe with 12 individuals while the largest troop is of Fulbari gate with 35 individuals. The average troop size is 23.71 with standard deviation 9.92. Three age groups were identified as infants, young, and mature. There are $14.46 \%$, $42.17 \%$, and $40.96 \%$ infants, young/juvenile, and mature simultaneously. $21.08 \%$ are male, $21.69 \%$ female, and 57.23 are of unknown sex (table 3). The sex ratio (male: female) from identified individuals is 0.97 . Each female has 0.67 infants during this season.

Table 3. Population of Assamese monkeys in SNNP.

\begin{tabular}{|c|c|c|c|c|c|c|c|c|c|c|c|c|}
\hline \multirow[b]{2}{*}{ SN } & \multirow[b]{2}{*}{ Troop name } & \multicolumn{3}{|c|}{ Age group } & \multicolumn{3}{|c|}{ Sex category } & \multirow{2}{*}{$\begin{array}{c}\text { Troop } \\
\text { size }\end{array}$} & \multirow{2}{*}{ 胥 } & \multirow{2}{*}{ œ } & \multirow{2}{*}{ 全 } & \multirow{2}{*}{ 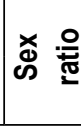 } \\
\hline & & Infant & Young & Mature & Male & Female & Unknown & & & & & \\
\hline 1. & $\begin{array}{l}\text { Rholche/ } \\
\text { Cha-gaun }\end{array}$ & 2 & 9 & 4 & 2 & 2 & 11 & 15 & \multirow{8}{*}{ 市 } & \multirow{8}{*}{ ๙̦ } & \multirow{8}{*}{ ڤ్ర } & \multirow{8}{*}{ बू } \\
\hline 2. & Mahabhir & 1 & 3 & 8 & 4 & 4 & 4 & 12 & & & & \\
\hline 3. & $\begin{array}{l}\text { Alchhe/Sikre } \\
\text { khola }\end{array}$ & 3 & 16 & 8 & 3 & 5 & 19 & 27 & & & & \\
\hline 4. & Sinche & 4 & 14 & 11 & 5 & 6 & 18 & 29 & & & & \\
\hline 5. & Fulbari gate & 7 & 12 & 16 & 9 & 7 & 19 & 35 & & & & \\
\hline 6. & Raniban & 4 & 10 & 13 & 9 & 7 & 15 & 31 & & & & \\
\hline \multirow[t]{3}{*}{7.} & $\begin{array}{l}\text { Sanagaun- } \\
\text { Mudkhu }\end{array}$ & 3 & 6 & 8 & 3 & 5 & 9 & 17 & & & & \\
\hline & Total & 24 & 70 & 68 & 35 & 36 & 95 & 166 & & & & \\
\hline & Percentage & 14.46 & 42.17 & 40.96 & 21.08 & 21.69 & 57.23 & & & & & \\
\hline
\end{tabular}

\section{Behavior}

Habituations lead the observation of monkeys close to 10 meters distance. Out of 78 hours total observation for behaviors, foraging/eating is the prime activity consuming $46 \%$ time followed by inactive behavior (19\%), locomotion (16\%), sleeping (12\%), grooming $(6 \%)$, and playing $(1 \%)$. A few events were recorded as aggressive/fighting behavior and licking salt. Reproductive relative behaviors were observed as copulation and vagina clearance. It was noticed sometime that some individuals were coughing and sniffing loudly. For the insight of Assamese behaviors a day events are presented herewith (fig.1). 


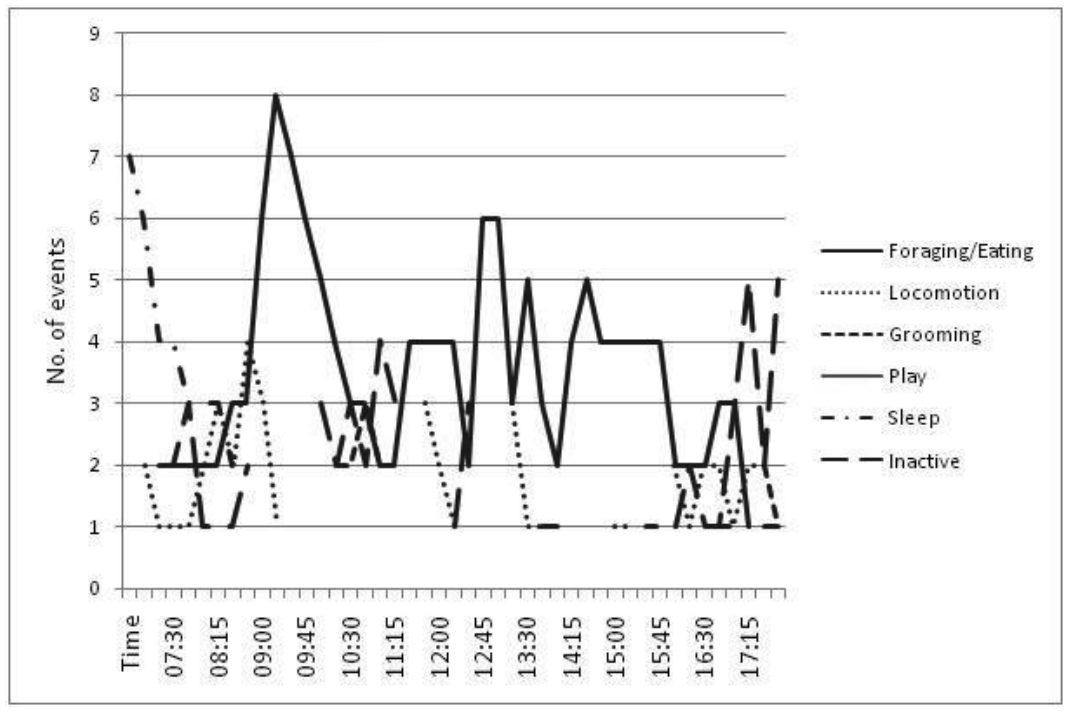

\section{Figure 1. Behavioral pattern of Assamese troop in Shivapuri Nagarjun National Park.}

\section{Morphology}

Chalise (2003) has observed the fur coloration of Assamese monkeys in Nepal varying from dark-brown to blackish-brown on the back, and whitish blonde-haired to ashy white on the abdomen. The Assamese monkeys in Shivapuri Nagarjun resemble the similar color pattern. The color pattern from this study has found to be varying among the individuals of the same troop. One distinguishing feature between pelage of Assamese and Rhesus macaque is that the former has reddish/brownish coloration increased toward shoulder while the later has reddish pattern increasing towards anal region. Like other sinica-group adult male and female has distinguishing facial coloration male with buffy color and female buffy to pinkish color (Fooden 1988, cited in Chalise 2003). As Chalise (2003) observed, adult female has pinkish coloration around the eyes sometimes up to cheeks, few females has found to have pinkish coloration around eyes with blackish tanned cheek. Variability in facial color is common in males also. Some males were found with pale skin-white face while some were darker. The pelage of infants and juveniles reflect the similar pattern. Most juveniles are lighter but a few found even black resembling some of the adults. The loin lacks red coloration completely while sitting pads were observed whitish in males. We have observed around 45 degrees slope of the tail not parallel to ground as described by Menon (2003). The males in SNNP were found to be quite larger than females (photo plate 1). The facial structure resembles to that of Rhesus with mongoloid type shape. The muzzle is short. The side-whiskers and beard are moderately developed as the case for most Assamese macaques (Fooden 1988, cited in Chalise 2003) projecting forward. The whorl in the head is commonly observed in both sexes. 

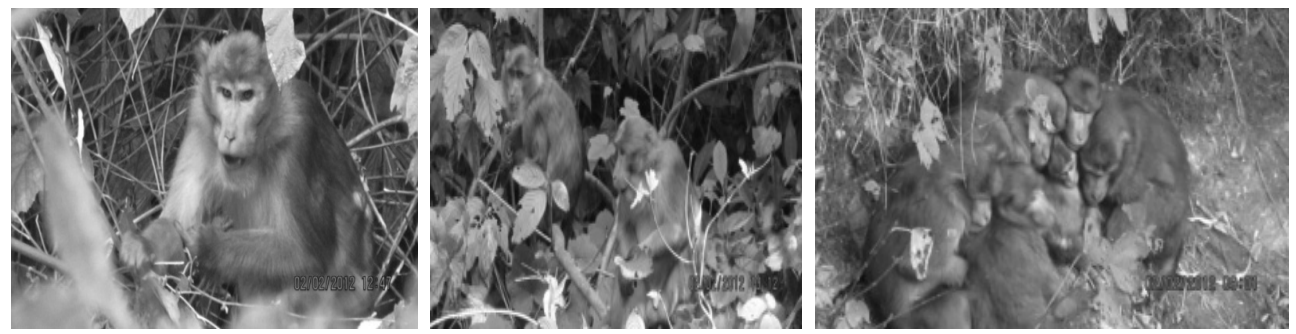

Photo plates 1. (From L-R): Adult male, adult female and close male and group resting.

\section{Distribution}

A troop was reported by Wada (2005) in Nagarjun area in 1985, after then the Assamese monkey in Shivapuri Nagarjun National Park long been unknown. The northern aspect of the park has some series of steep altitudinal gradient and cliffs (some overhanging) with higher waterfalls best suitable habitat for Assamese monkey. The southern part of the park is relatively gentle in slope, lacks larger cliffs, heavily disturbed by humans as well as rhesus troop. Although, habitat overlap by the Rhesus and Assamese monkeys observed in Fulbari gate, SanagaunMudkhu, and Raniban was not the case in other parts of forest. Assamese monkeys were observed mostly in north aspect with relatively more serene environment while the Rhesus macaque is found distributed to southern part up to forest margin near the human inhabitants. Macaca assamensis recorded in moist areas (Chalise 2007) and the case was similar for the troops found in SNNP, while Fulbari Gate and Raniban troop observed wandered forest area whole day and at night they were observed halting in the cliffs at the bank of the streams with waterfalls. The Hanuman langurs were not observed during this field research.

\section{Population}

The average troop size is 23.71 with standard deviation 9.92 and range of 23 (12-35) larger than the size estimated by Wada (2005) with range 5-34 (19.1) and 20.71 for Langtang National Park. There is slightly less male population than female (sex ratio 0.97 ) which is near to Chalise (2003). He had calculated some higher sex ratio in MBNP (1:1.6 in 1997) and (1:2) in LNP than SNNP.

\section{Habitat and vegetation composition}

The SNNP has four types of forests. The sub-tropical habitat was used by Fulbari gate troop while others have sub-tropical to temperate forests. The common tree species found were Schima wallichi, Castanopsis tribuloides, Castanopsis indica, Quercus lamelosa, Alnus nepalensis, Myrica esculenta, Pyrus pasia, Toona ciliata, Myrsine semiserrata, Desdmodium multiflorum, Rhus javanica, Myrsine capitellata, Taxus wallichiana, Litsea salicifolia, Symplocis theifolia and a few thorny bushes of Rubus foliolosus, Polypodium amoenum and a few unknown climbers.

\section{Vocalization}

Communication between individuals was observed with very low pitched voice that can be listened far from 30-40 meter radius. A high-pitched voice is common to aware the troop about 
possible threat. During habituation period alpha male frequently produced a loud call sounding "Kkuttaankk, Chinnkk" when observer comes pretty close to his troop. It was observed that the infants and juveniles normally go to the residing area prior to the matured ones with a long call possibly a call for gathering by "Uunngg, Eiuuu, Chingk". The sounds "Pio", "Thruuu", "Quinch", "Chrkhyak", "Khio" and "Chianck" were very similar as described for MBNP troops (Chalise 2003).

\section{Behavior}

Behavior study was carried out for a whole day (from 7:00 to 18:00). The troop had missed frequently during observation. The general activities reflected a multimodal activity pattern for a day (fig. 2). It is obvious from the diagram that Assamese monkey lags early wake up (sometimes until 9:00) and foraging starts around 8:30 and peaks during 10:00. Foraging is highest in observed data may be due to seasonal influence. In case of MBNP and LNP also it was recorded higher percentages (Chalise 2003). Locomotion in late morning is common while it was very less in comparison to previous studies (Chalise 2003). Assamese monkeys spend their time to depart from resting sites and to arrive. It is reported (Menon 2003) that it travels along the ground laying its tail parallel to the ground, reports it but this study found that tail remains around $45^{\circ}$ sloping towards ground. Troop usually remains inactive during early morning, noon, and evening when they usually groom, play, and sleep. Sexual activities were observed accompanied with before or after grooming.

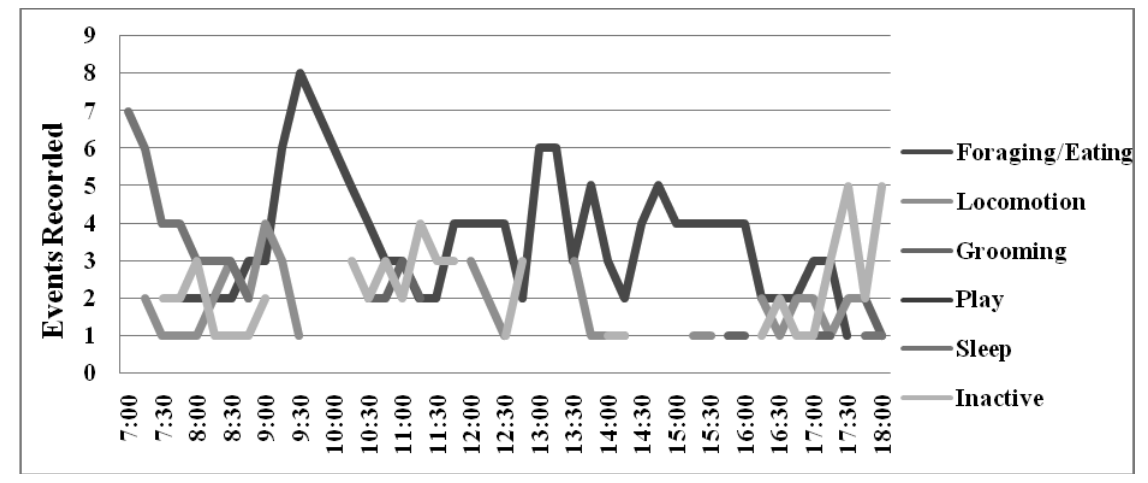

Figure 2. Diurnal time specific behavior pattern of Assamese monkeys in SNNP.

\section{Foraging/Eating}

Foraging comprises $46 \%$ time budget for Alche/Sikre Khola troop. Foraging study in winter months for Assamese monkey troops in this troop reveals that they rely on consuming tender leaves and burgeoning twigs followed by foraging on seeds. A total of 161 foraging events were recorded. Monitoring team was able to track 70 occasions $(43.48 \%)$ when the species consumed was recognized while 91 events (56.52 \%) were not known. Out of known species, Kalo aisalu (Rubes paniculatus) the main species preferred by the troop followed by Bilaune (Maesa chisia), Mayel (Pyrus pasia) and Moss (fig. 3). Foraging along the streamlets for benthic organism is common sharing $5.71 \%$ on dietary equation. Besides, feeding on roots, rock licks, 
mushroom, lichens are additional possibly for mineral supplement. It was observed that $38.24 \%$ diets are supplied by leaves and twigs while $35.29 \%$ cover by seeds (fig. 4). Moss and other epiphytic plants, benthic insects, roots, mushrooms, rock licks are additional which is similar to previous study in Nepal (Chalise 1999, 2003). Drinking was never observed.

The result contrast with diet analysis by (Zhou et al. 2011) in limestone habitat of Nonggang, China provided that the leaves and twigs contribute here for only $38.24 \%$ diet while the later has $74.1 \%$ and seeds comprises of $35.29 \%$ in SNNP while that constitute only $17.4 \%$ in Nonggang, China.

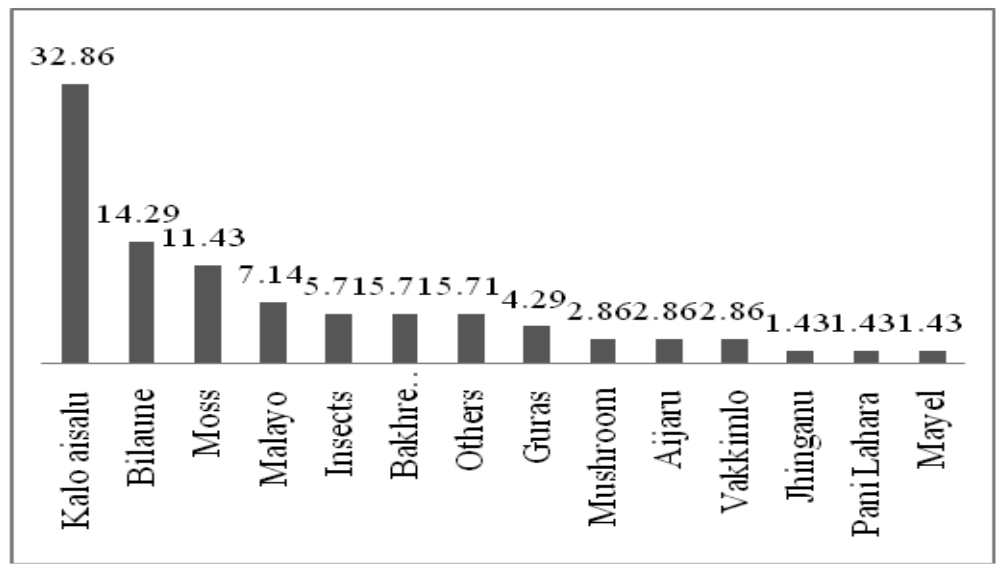

Figure 3. Food preference of Assamese monkey in SNNP.

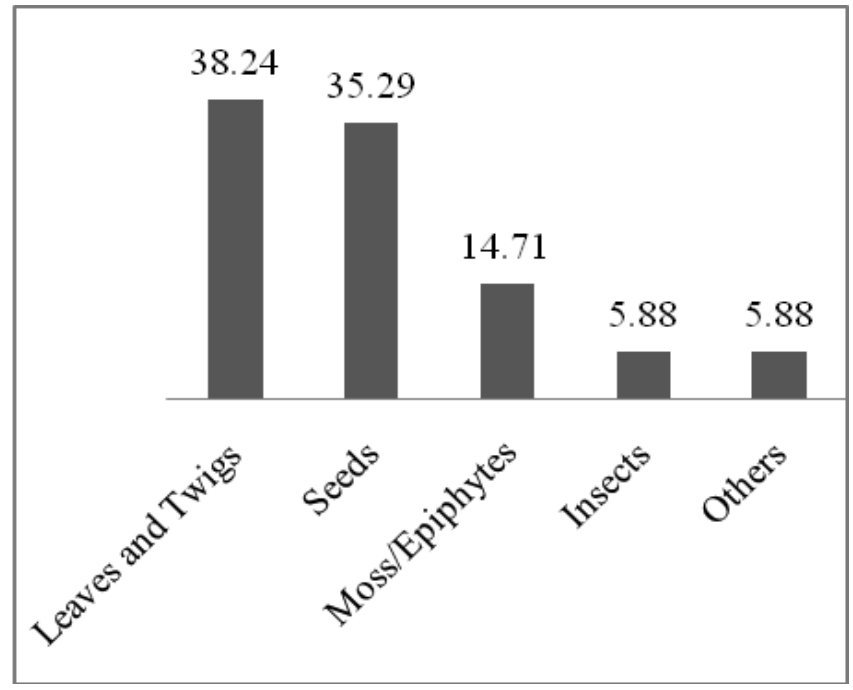

Figure 4. Food categories consumed by Assamese monkey in SNNP. 


\section{Other behavior}

It was found that Assamese monkey remains inactive particularly in the early morning and noon however, they stay in body contact in close relatives. It was observed that body contact between closely related individuals were possible, showing affection between individuals. Sharing common ground is usual on sleeping with multiple male and females with their young (photo plate 1). The infants and young are observed slept between matured individuals. Among the activities, playing was particularly performed by infants and juveniles. Grooming was commonly understood as a mechanism to strengthen individual relationships and expression of hierarchy, invests $6 \%$ time. It was very less in comparison to MBNP and LNP (Chalise 1999: $9-13 \%$, Chalise 2003: $12-20 \%)$. Sleeping is common behavior, residing on the rock terraces near by the waterfalls, observed as late as 9:00 AM spending more than grooming (12\%).

The study revealed that there exist at least seven troops of Assamese monkeys in Shivapuri Nagarjun National Park. The average troop size is 23.71 with standard deviation 9.92. The Assamese monkeys were observed distributed towards northern aspect of Shivapuri area of the park and eastern part of Nagarjun forest. Assamese monkey preferred serene environment except a troop (Fulbari gate troop). The local estimated more troops than we observed in the park around Nagarjun forest. The focal troop behaviors were categorized into six types viz. foraging/eating, locomotion, grooming, play, sleeping, and inactive. It is concluded that Assamese monkeys in Shivapuri Nagarjun National Park spend most of their time in foraging while playing is the least favored activity. Grooming is a regular behavior to strengthen social relationship within troop.

\section{ACKNOWLEDGEMENTS}

We are grateful to the following institutions and funding agencies which supported the field works: Shivapuri Nagarjun National Park office, Department of National Parks and Wildlife Conservation (DNPWC) Babarmahal, Nepalese army deployed in this park as a protection unit. Local respondents are thankful for their kind coordination and support in fieldwork. Their guidance towards potential resting sites was the key for finding the troops. Thanks to Nepal Biodiversity Research Society and Randall C. Kyes (University of Washington) for their support to conduct Conservation Biology Training Program and Wildlife Survey that initiated this study. Thanks to Mr. Laxman Khanal and Rajan Poudel for their assistance in fieldwork. The study team is pleased to thank Mr. Madhav Khadka, Gokarna Thapa, and Kamal Thapa for their support.

\section{REFERENCES}

Altman, J., 1974. Observational study of behavior: sampling methods. Behavior, 48:227-267. Boonratana, R., M. Chalise, J. Das, S. Htun and R. J. Timmins, 2008. Macaca assamensis. In: IUCN 2012. IUCN Red List of Threatened Species. Version 2012.2.www.iucnredlist.org Accessed on 16 June 2013.

Chalise, M. K., 1997. Monkeys from Makalu-Barun Conservation Area (MBCA). Natural History Soc. Nepal. Bull., 7(1-4):30-34. 
Chalishe et al. : Ecology and Behavior of Assamese

Chalise, M. K.,1999. Some behavioral and ecological aspects of Assamese monkeys (Macaca assamensis) in Makalu-Barun Area, Nepal. Nepal Journal of Science and Technology, 1:85-90. Chalise, M. K., 2000. Report on the Assamese monkeys (Macaca assamensis) of Nepal. Asian Primates, 7(1-2):7-11.

Chalise, M. K., 2003. Assamese Monkeys (Macaca assamensis) in Nepal. Primate Conservation. The Journal of the IUCN/SSC Primate Specialist Group, 19:99-107.

Chalise, M. K., 2005. Characteristics of the Assamese monkey (Macaca assamensis) of Nepal. ASP Congress August 17-20, American Journal of Primatology, 66 (supp)1:195.

Chalise, M. K., 2008. Nepalka Samrakshit Banyajantu (Nepal's Protected Wildlife). Shajha Prakashan, Lalitpur Kathmandu Nepal, pp116+12 (in Nepali).

Chalise, M.K., 2008a. Primate census in Kathmandu and west parts of Nepal. Journal of Natural History Museum, 23:60-64.

Chalise, M. K., 2010. A study of Assamese monkey in Sebrubeshi of Langtang National Park, Nepal. Journal of Natural History Museum, 25:54-61.

Chalise, M.K., 2011. Notes on Hanuman langurs and Assamese monkeys of Central Zoo, Nepal Central Zoo Newsletter Quarterly Publication, 39:3-4.

Chalise, M.K., 2012. Nepalese Primates and their Conservation Status. Abstract book, 56 p. SEA Bangkok.

Chalise, M.K., 2012a. Monkey species and Nepali Assamese monkey. Hamro Sampada, 12 (1):92-98 (in Nepali).

Chalise, M.K. (Press). Fragmented Primate Populations of Nepal. Primates in Fragments, Chapter No.: 22, Code no 0002001982 Springer Book series.

Chalise, M. K., J. B. Karki and M.K. Ghimire, 2005. Status in Nepal: non-human primate. Special issue published on the occasion of $10^{\text {th }}$ Wildlife Week, 2062. DNPWC/ HMG Nepal, pp 19-26. Chapagain, D. and J. Dhakal, 2002. g]kfndf ;fOl6; sfof\{Gjog -kl/ro / klxrfg k'l:tsf_= Kathmandu: Department of National Parks and Wildlife Conservation/WWF Nepal.

IUCN/SSC, 1999. Primate specialist group: the Assamese monkeys (Macaca assamensis) of Nepal. Asian Primates, 7(1-2):7-265.

Kawamoto, Y., M. Aimi, T. Wangchuk and Sherub. 2006. Distribution of Assamese macaques (Macaca assamensis) in the inner Himalayan region of Bhutan and their mtDNA diversity.

Primates, 47(4):388-392.

Martin, P and P. Bateson, 1993. Measuring Behaviour. Cambridge University Press, NY, USA. Medhi, R., D. Chetry, B. Choudhury and P. Bhattacharjee, 2007. Status and diversity of temple 
primates in northeast India. Primate Conservation, 22:135-138.

Menon, V., 2003. A Field Guide to Indian Mammals. s.I.:Dorling Kindersley (India) Pvt. Limited. Nepal, H.K. and M.K. Chalise, 2007. Habitat utilization of Rhesus monkey (Macaca mulatta, Zimmermann) in Shivapuri National Park, Kathmandu, Nepal. National Seminar on Sustainable use of Biological Resources ECOS, IOF, PN Campus, Pokhara, Abstract Book, pp 89-90. Pandey, B. P., 2010. A Report on presence/absence survey of Clouded leopard (Neofelis nebulosa) in Shivapuri Nagarjun National Park, Nepal. DNPWC, Kathmandu, Nepal.

Sanjay, M., B-J. Douglas, D. Wolfgang, E. Ardith, K. Ajith, S. Mewa M.M. Feeroz, M. K. Chalise, P. Padma and W. Sally, 2003. Status of south Asian Primates: Conservation Assessment and Management Plan (CAMP). Workshop Report, Zoo Outreach Organization/CBSG-south Asia, Coimbatore, India, pp viii+432.

SNNP, 2010. Shivapuri Nagarjun National Park, Brochure. Kathmandu: Shivapuri Nagarjun National Park, Panimuhan, Budhanilkantha, Kathmandu, Nepal.

Timmins, R.J. and J.W. Duckworth, 2013. Distribution and habitat of Assamese macaque Macaca assamensis in Lao PDR, Including its Use of Low-altitude Karsts. Primate Conservation, 26:103-114.

Wada, K., 2005. The distribution pattern of Rhesus and Assamese monkeys in Nepal. Primates, 46:115-119 DOI 10.1007/s10329-004-0112-x.

Zhou, Q., H. Wei, Z. Huang and C. Huang, 2011. Diet of the Assamese macaque Macaca assamensis in lime-stone habitats of nonggang, China. Current Zoology, 57(1):18-25.

\section{AUTHOR'S ADDRESS}

Mukesh K. Chalise ${ }^{1}$

Central Department t of Zoology, Tribhuvan University, Kirtipur, Kathmandu, Nepal (email: mukesh57@hotmail.com)

Gopal Prakash Bhattarai ${ }^{2}$ and Bishnu Pandey ${ }^{2}$

Shivapuri Nagarjun National Park 